dispose to temporary paralysis, as it is met with so often in this state, but it may be questioned whether paralysis would sufficiently account for rupture of the bladder from over-distension. As an example of the persistence of spasm, a case may be mentioned here which occurred while I acted as house-surgeon in the Glasgow Royal Infirmary, of a man who was admitted suffering from retention of urine from spasmodic stricture, consequent on excessive indulgence in alcohol. I passed a No. 10 catheter easily, and withdrew ninety ounces of urine, carefully measured. The only result was paralysis of the bladder for some time. The semi-unconsciousness in the present case seems to have been continuous from the Saturday till death, the alcoholic stupor gradually merging into the drowsiness and coma of uræmic poisoning.

N.B. The preventability of rupture in this case is obviously beyond comment.

Glasgow.

\section{A GRAVE COMPLICATION OF TYPHOID FEVER.}

BY C. F. MAUNDER,

SURGRON TO THE LONDON HOSPITAL.

TYPhOID FEVER having just lately attracted a good deal of attention from the profession, two cases associated with hernia which have come under my observation will have some interest for it.

CASE 1 is that of a feeble old gentleman seen by me in consultation with Dr. Gillies, after three or four days' illness. He had been the subject of what proved to be a direct inguinal hernia of the right side, which the doctor thought he had partially reduced by taxis; but vomiting persisted, and was now stercoraceous. Aperient medicine had been rejected by the stomach, and there was constipation. His illness apparently began with sudden pain in the right inguinal region. I explored the inguinal swelling, and disclosed an old hernial sac, empty, with a very narrow neck indeed, and loaded with subperitoneal fat. Some days subsequently I heard from Dr. Gillies that our patient was undoubtedly the subject of typhoid fever, and, later still, that he had recovered, in spite of the surgeon, but much to the credit of the physician, as I think.

Of course, in the early stage of possible fever, with no special symptom to guide, obstinate and stercoraceous vomiting with a history of hernia and a swelling in a hernial region demand an exploratory operation. It is preferable to perform such an operation unnecessarily than to risk the possibility of death from strangulated hernia.

CaSe 2.-A young man who had been ailing for many days was the subject of an inguinal hernia of the left side. The belly was tympanitic and tender, and he kept the lef thigh flexed on the pelvis to relieve discomfort in the inguinal region. Handling the inguinal swelling caused pain Constipation with nausea and sickness existed. His dull, listless aspect led me to look for a rose rash, and three or four spots were found. I now obtained the aid of Dr. Down, who pronounced the case to be one of typhoid fever. The question of operation was no longer entertained, and the progress of the case showed it would have been superfluous.

In this latter instance, but not in the former, the duration of the illness associated with rose rash materially aided the diagnosis; while, on the other hand, the flexed left thigh and tender bubonocele tended to throw the observer off his guard. Queen Anne-street

\section{ON THE}

CURE OF A LARGE VARICOSE ULCER BY TANNING WITH BABOOL BARK.

By SURGEON J. ROCHE, M.D., Bombay ARMY, CIVIL SURGEON, ROTRRE, INDIA.

CAPt. F- commanded one of the Indus Steam Flotilla Company's steamers which ply on the river Indus between Rotree, in Scinde, and Mooltan, in the Punjab. His habits were those of a free liver at table, without being intem. perate. His weight, I should say, was nearly sirteen stone.
He was under my care for treatment in March, 1871, with a large varicose ulcer in the front and outer part of the leg. For many years be had been inconvenienced by varicose veins in the same leg, extending up the thigh to the groin, and, to relieve the consequent sense of weight and distension in the limb, he had worn an elastic stocking. Tho varicosity had affected the minutest veins, so as to change the colour of the integument in patches of black, brown, or red.

A few months before his application to me, when he was returning to his ship at night, he fell across the iron rails which are close to the river to permit the railway carriages to be run in proximity to the steamers whilst discharging cargo. He paid little attention to the contusion and abrasion which resulted, and proceeded to Mooltan as usual in command of his ship.

The great difficulty in navigating the river Indus when it is low in the cold weather, and to avoid the shifting sands in the bed of the river, necessitate the commander's unremitting attention from early dawn to dark every day. The standing posture which Capt. F- was constrained to maintain quickly inflamed his leg, and he was forced to discard the use of the elastic stocking. The voyage to Mooltan in the cold weather is tedions in the extreme, and, though a distance of 500 miles, has been known to occupy six weeks, from the steamer having rested on sands. Towards the end of March, as the river rose, the navigation became easier, and Capt. F- was able to give intervals of rest to his painful limb on the return voyage.

When he applied to me there was an inflamed and sloughing ulcer on the front and outer part of the leg. The central part of the ulcer looked like meat which had been exposed to the sun till decomposition commenced, and from it was issuing an ichorous fluid. The circumferential portion was covered by a shining and translucent epidermis, which was at once perceived to be dead by the vitreous and almost crystalline character it gave to the tissues underneath. The foot and leg were much greater in girth than their fellows on the other side.

The treatment prescribed embraced rest, elevation of the limb, poultices, a cholagogue, and abstemiousness. In a few days the sloughy surface was cleared, and there was left a large sore, red, angry, and painful-very like one consequent on a burn. Carron oil was used as dressing, and seemed to answer well for a few days. The angry appearance continued, if not increased. Bread-and-water poultices (over which a lotion, containing forty grains each of tannic acid and alum, with a drachm of tincture of belladonna, to ten ounces of water, was poured) were used. The ulcer soon lost its irritable character, but it became pale and in dolent. The new epidermis which was forming was quite unhealthy. A dressing composed of half-an-ounce each of castor and turpentine oil to six ounces of linseed oil was tried, but the patient could not bear it longer than about two hours, when he said he felt as if a red-hot iron was fixed on his leg. Zinc lotion (a drachm and a half to eight ounces of water) was used. Tannic acid and alum lotion was, after some days, again had recourse to; the pledget of lint wrung out, which was covered over with a poultice or a piece of oiled silk at night, as a less or greater temperature was desired to be maintained. I am of opinion that the temperature maintained by a poultice is much less than that kept up by a piece of oiled silk. Strapping was tried when the granulations were large and weak. Bandaging the foot and leg to a short distance from the raw surface was done regularly. Under each form of dressing - the sedative when angry and irritable, the stimulating and supporting when indolent, cold lotions and water-dressing when inflamed, and poultices when sloughy - the ulcer did temporarily well, and many times changed its character. It frequently diminished in size to about two inches and a half in diameter, and as often enlarged to its original dimensions of nearly six inches. This intractable feature had almost completely exhausted the patience of the sufferer and myself, and lasted nearly two months. The internal medicines exhibited comprised sedatives, tonies, purgatives, and iodide of potassium.

Skin-grafting was of ten thought of, but I had not much faith in it, as some of the uloer was more than once heitled over by skin or its analogue, and which as often had died off. It occurred to me to get the ulcer a little weak with water-dressing, and literally tan it. I asked Capt. F- to 
send his servant for some babool-bark (Acacia catechu) or pomegranate-bark, and have them ground to fine powder in a mortar. In my leisure at Rotree I analysed babool-bark, pomegranate-bark, and mango-bark, and found the quantity of tannic acid contained to be about 19 per cent. in the first, or nearly twice that of oak-bark; about 5 per cent. in the second; and about 7 per cent. in the third. The mangobark contains a large quantity of gummy or starchy matter, which forms a fetid coagulum with hot water, that precluded its use. The babool, as the most easily procured, was the one used, being ground to a fine powder, and made into a poultice with hot water. The leg was enveloped in a layer of it twice a day, and the most astonishing success was the result. The skin of the whole leg got firm, the size of the limb seemed to diminish, and the ulcer was healed completely in a few days. The new skin as well as the skin of the leg seemed healthy and firm, and was rendered somewhat darker in colour.

The tanning process will answer best when the granulations are prominent and slightly indolent. If they be not sufficiently prominent, stimulating dressings should be applied to the backward portion of the sore or burn to bring it forward.

Tannic acid pure, nor a solution, however saturated with it, will not have the effect. The tannin must be in the nascent condition, as for making leather.

The result of this tanning method was most satisfactory to me, as it was most gratifying to my patient. I believe it is superior to and may supplant skin-grafting in the treatment of burns and ulcers when superficial, extensive, and granulating.

Hardwicke-street, Dublin.

\section{A CASE OF CEPHALOTRIPSY.}

By R. J. CAREY, M.A. CaNtab.

PrLvic distortion requiring cephalotripsy is rare even in large towns, but in a purely country practice, like mine, it is, I believe, almost unknown.

On Sept. 17th Mrs. H-, aged forty, primipara, sent for me about 5 o'clock P.M., having been in labour some seventeen hours. The os would just admit two fingers, and the uterine walls were rigid and very thin (by which I do not allude to the knife-like edge common in primiparæ). I gave her thirty minims of laudanum, and left. At 10 P.M. the pains were still very weak, but the os was softer, thicker, and about two inches across. I now made a careful examination, and concluded that the antero-posterior diameter was normal, but that the ischial tuberosities were little, if anything, more than two inches and a half apart. The perineum was thick and strong. I at once called in Mr. Ansell, of Fenny Stratford (about 11 P.M.). Weagreed to defer operations till daylight, so I gave twenty-five grains of chloral hydrate to give the patient some sleep, but the dose was not enough to do so.

Sept. 18th.-At 6.30 A.m. we found the os fully dilated, the pains weak, and the membranes not tense. I now perforated, and cut the cranial bones in several directions with Smellie's straight scissors, after which the head collapsed so much that I thought I could draw it through. By combined external and internal version I got hold of a foot, and extracted without much difficulty by turning (for the child's bones were very delicate, and moulded themselves well) till we came to the head. After we had tried in vain to get this through as it was, I perforated the occipital bone, and broke down all the hinder part of the skull; but still no traction we dared put on could get down the jaws or base of the skull, which rested easy above the ischia. I now pushed it back a little, and got in Dr. Hicks's cephalotribe, and crushed the head and jaws, after which I tried to extract by the cephalotribe, but, from the position in which it held the head, the antero-posterior diameter of the latter was so great that the perineum would have been terribly ruptured had we proceeded. I therefore crushed a little more, removed the instrument, and then managed to extract the head about 7.30 A.M. After removing the after-birth, we found there was contraction at the brim as well as at the outlet. Happily, neither the perineum nor uterus received

any injury whatever, and the patient, who did not have chloroform, felt no pain to speak of throughout except while I turned. She has gone on well since, is cheerful, feeds well, and has a good pulse and plentiful pale lochia.

I do not know how I should have got over this case if I had not had a cephalotribe. I thought of Dr. Braxton Hicks's plan of picking off the calvaria and canting the base; but had I done so the perineum must have gone, not to mention the damage that would be done to the bladder \&c. by the sharp points left; and no craniotomy forceps I have seen would break up the base. In 1871, Mr. P. B. Giles and I (then senior and junior obstetric assistants of University College Hospital) had a case of violent accidental hæmorrhage where, the child being dead, and the os not fully dilatable, perforation and removal of the calvaria was performed, but the woman sank before the base could be extracted. Had we had a cephalotribe, we conjectured that she possibly might have been saved. We tried the craniotomy forceps without avail. These extreme cases are doubtless very rare, but when they do occur the saving of time effected by the cephalotribe is immense. I am surprised to find how few general practitioners have the sacrificial instruments. In fact, except one, none of my medical friends have anything more in their bags than a short forceps, a curved scissors, and a crotchet, which of course, in cases like the aforesaid, are absolutely useless; yet cases must certainly occur at times where a woman is lost from her attendant not being suitably equipped himself, or able to call in a friend who is; but they would naturally be hushed up. Few hospital students, except the obstetric assistant himself, feel any interest in operative midwifery; for, first, the chances are that in twenty cases they may have no operations at all (one gentleman told me that he had never been present at an actual forceps case till after he got the M.B. London midwifery scholarship); secondly, what operations there are are reserved for those in authority over them. So they start into general practice with a bonk knowledge of obstetrics, and trusting to Providence not to send them hard cases.

I must not conclude without acknowledging the aid I received from Mr. Ansell in this case. As I used the weapons, I have had to use the first person only too often; but the success of the operation is equally due to his able assistance ; and as his opinion entirely, on every point, coincided with my own, it is a satisfactory guarantee of the correctness of my conduct.

Fenny Stratford, Bucks,

\section{A a ditrror}

\section{H O S P T TAL ${ }^{\text {ox }}$ P R A C T I CE, BRITISH AND FOREIGN.}

Nulla antem est alia pro certo noscendi via, nisi quamplurimas et morbornm et dissectionum historias, tum aliorum, tum proprias collectas habere, et inter se comparare.-Mongagr De Sed. et Caus. Morb., lib.iv. Procemium.

\section{UNIVERSITY COLLEGE HOSPITAL.}

PENETRATING GUNSHOT WOUND OF THE ABDOMEN; INJURY TO THE SPLEEN, STOMACH, AND LIVER; DEATH.

(Under the care of Mr. ErICHSEN.)

IN the following case there was unusually little shock considering the nature and extent of the injuries and the circumstances under which they were received. The patient had not only sustained serious damage to important viscera, but was without the benefit often afforded by a previously existing excitement; and, being alone for many hours, he had time to reflect on his wounds, and to add mental anxiety and moral depression to his physical suffering. All this is the more remarkable because there is evidence of a severe concussion of the body; for the liver was not only wounded by the bullet, but was extensively lacerated by the concussion of explosion.

W. H. B- , aged thirty-five, at 9.30 P.M., May 29th, was examining a loaded pistol, which exploded, and the bullet entered the upper part of the abdomen. The patient did 